\title{
水平噴流式煙制御システムに関する実験的研究 EXPERIMENTAL STUDY ON SMOKE CONTROL SYSTEM WITH HORIZONTAL AIR JETS
}

\author{
原 哲夫*1, 中浜慎司*2, 嵐城太郎*3, 山名俊男*4
}

Tetsuo HARA, Shinji NAKAHAMA, Taro ARAKI

and Toshio YAMANA

\begin{abstract}
Horizontal air jets system was developed to keep smoke out of the safe area, which was designed to allow free access of people from escape routes. Full scale experiments were conducted to study the distribution of air velocity, temperature and $\mathrm{CO}_{2}$ concentration in real pool fires. Smokeproof ratio and air change rate of the safe area were estimated by the air balance model from results of the experiment. Horizontal air jets were numerically simulated using the standard $k$ - $\varepsilon$ model of turbulence. Computed results were compared with experimental data to assess the accuracy of prediction. The smokeproof effect of horizontal air jets in crowd movement was evaluated with dummy bodies arrayed in front of air nozzles.
\end{abstract}

Keywords : Smoke Control, Smokeproof, Horizontal Air Jets, Numerical Analysis, $k-\varepsilon$ Model, Evacuation 煙制御, 遮煙, 水平噴流, 数值解析, $k-\varepsilon$ 王 $N$, 避難

\section{1.はじめに}

付室や階段室を煙から防護し避難者の安全を確保する煙制御システム

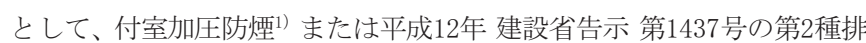
煙2) あるいは階段加圧防煙3) が採用されてきた。これらの煙制御システ公 は、煙流動シシュレーション゙)を用いて計画され、実建物において安全性が検 証されている。

しかし、廊下一付室間または階段室間の開口部（扉）における防煙ま たは遮煙の有効性については、給気口の位置や吹出速度により遮煙開 口部への動圧の影響が見受けられる等、検討すべき項目も多い。5)

筆者等は有効な遮煙効果を達成できる煙制御方式として、新たに水 平噴流式煙制御シ人云（図1）を検討した。

本シ人テムは、避難通路の両側の壁から気流を吹出し、噴流による空気膜 を形成して防護空間の遮煙を行うものであり、病院等の災害弱者また は地下通路等の大量の避難者が扉やシかッ多に妨げられることなく安全 に避難できる利点を有している。実規模実験6)7) により本シ行ムの遮煙 効果を検討したので、本報ではその結果を報告する。

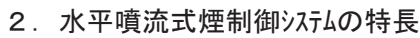

本シ久公は、従来の加圧防煙の様に付室等の防護空間に給気して内圧 を高め、扉開閉時の遮煙をはかるシステムとは異なり、以下に示す特長か ら建築物の安全性および機能性を向上できる。

\section{(1)遮煙効果の確保}

・開口部の遮煙効果を安定して確保できる。加圧防煙の様に給気方

向、遮煙場所により気流が不安定となることはない。

・吹出し気流は避難者の通過に支障なく、遮煙効果も低減しない。

\section{(2)通過障害の低減}

・扉等が不要なので、加圧防煙の様に防護空間の圧力が上昇して開 閉障害を生じることはない。

・扉やシャ多一の省略により災害弱者や大量の避難者が通過する際の 安全性を向上できる。（車椅子等の通過が容易）

(3)環境条件の維持

・避難者は遮煙空間を通過した後、気流の影響の小さい防護空間で 救助を待つことが可能である。

・防護空間は換気効果により、空気温度、必要外気量等の環境条件 を維持できる。

(4)作動シ久テムの簡易化による高信頼性確保

・防護空間の圧力が上昇しないので、加圧防煙の様に圧力制御機構 を設ける必要はなく、作動信頼性が高い。

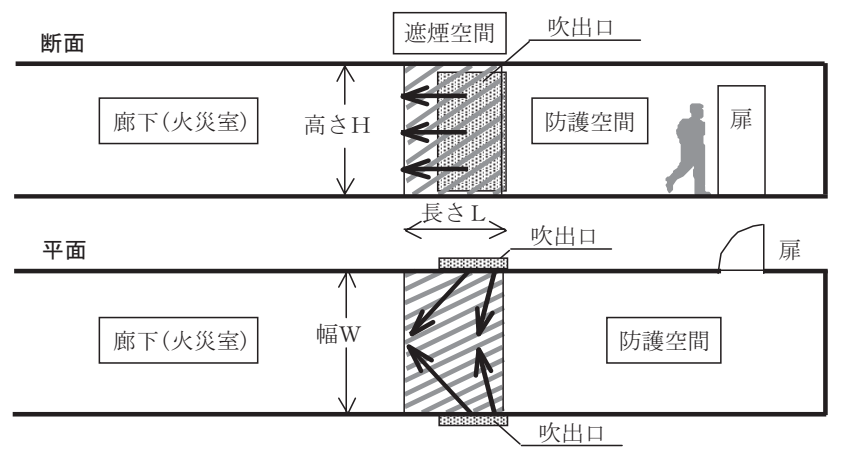

図 1 水平噴流式煙制御シ人元ムの概念
$* 1$ 大成建設設計本部 博士 (工学)

$* 2$ 大成建設技術センター 修士 (環境科学)

*3 大成建設技術センター

*4 国土交通省国土技術政策総合研究所主任研究官
Taisei Corp. Design Division, Dr. Eng.

Taisei Corp. Technology Center, M. Environmental Sciences

Taisei Corp. Technology Center

Senior Researcher, National Institute for Land and Infrastructure Management 


\section{3. 検討課題}

本シ行は、両側壁の吹出口から遮煙空間（幅W, 長さ $\mathrm{L}$, 高さ $\mathrm{H} ） に$ 向けて斜めに給気し、遮煙空間の中央部分では給気が合成された気 流の動圧によって、さらに、吹出口近傍では吹出気流により遮煙を 行う。（図 1）これにより遮煙開口部に対し、信頼性の高い遮煙効果 の達成を目的としている。

本研究では、発熱時におけるシ行ムの遮煙効果を定量的に把握する ことを目的に、以下の手順に従い検討を行った。

（i 基礎実験として、発熱がない条件下における気流性状測定 （ii）火災を想定した条件下での熱性状測定（防護空間への熱影響確認） (iii)遮煙効果の定量化を目的とした $\mathrm{CO}_{2}$ 濃度測定 (iv)模擬避難者による遮煙効果への影響測定

火源近傍では熱の影響が気流性状に及ぶと考えられるが、本研究で は吹出口付近と防護空間の温度上昇測定から、防護空間側への遮煙 効果をもたらす気流に対して、火源の熱による影響が小さいことを 確認する。さらに、 $\mathrm{CO}_{2}$ 濃度測定を行うことで、遮煙効果の定量化を 試みる。また、（i ）と（ii）については、排気等の外乱条件をできる 限り抑制した給気のみ作動 (排気量 $0 \mathrm{~m}^{3} / \mathrm{h}$ ) の个一スを対象に、CFD 解析 と実験結果の比較を行う。なお、発熱の有無によって、気流性状は 異なると考えられるが、発熱時の気流測定は困難であるため、遮煙 効果については、（iii）の $\mathrm{CO}_{2}$ 濃度測定により定量化を図った。

\section{4．気流性状・熱性状の実験}

\section{1 実験施設}

実験室および測定点を図 2, 3 に示す。実験室は幅 $2000 \mathrm{~mm}$, 高さ 2530 $\mathrm{mm}$ であり、廊下 (火災室) (長さ $6150 \mathrm{~mm}$ )、遮煙空間 $(1100 \mathrm{~mm}) 、$ 防護空 間 (3950 mm) からなる廊下状空間を想定した。なお、今回の実験では、 防護空間および遮煙空間の前面空間を廊下と称した。避難者の通過空 間である廊下は、通常は非火災室として扱われるが、遮煙効果に対す る火源条件を厳しくするために、吹出口近傍に火源を設置した。

遮煙空間の両側壁に刎卅状の吹出口（幅 $80 \mathrm{~mm} \times$ 高さ $2500 \mathrm{~mm}$ )を片側に 2 個ずつ合計 4 個を壁に埋め込夕設置した。吹出角度は各片側におい て、壁に対して鉛直方向から $40^{\circ}$ およ゙ $10^{\circ}$ 水平に廊下側に傾け、廊 下の長手方向中心線を両㘗からの吹出方向の合流点とした。垂直方 向の吹出しは、下部を $-40^{\circ}$ 、中央部を $0^{\circ}$ 、上部を $+40^{\circ}$ に漸次変化させ、 床面、天井面に気流を吹き付けて遮煙効果を高めた。

なお、予備実験として、吹出口数や吹出角度を変化させたケ一スを数例 実施したが、発煙筒 (図 2, 火源着火直前に発煙)の煙により遮煙効果 を確認できたのは上述のケースであった。よって、この吹出し条件によ り、本実験を行うこととした。

実験室の開口条件は、廊下側については下流端側面の両側壁に開口 (幅 $0.85 \mathrm{~m} \times$ 高さ $2.53 \mathrm{~m} \times 2$ ヶ所 $=4.3 \mathrm{~m}^{2}$ )を設けた。 $4.3 \mathrm{~m}^{2}$ の開口面積 を開口率 $100 \%$ とする。防護空間側の上流端は、階段室等への経路と して設置される扉の隙間から防護空間外一漏気が発生することを想 定し、上流端の壁面積(約 $5.0 \mathrm{~m}^{2}$ )の $1 \%\left(0.05 \mathrm{~m}^{2}\right)$ の对卅状開口(幅 50 $\mathrm{mm} \times$ 高さ $1000 \mathrm{~mm})$ を設けた。給気空気を強制排出する排煙口 $(900 \mathrm{~mm}$ $\times 900 \mathrm{~mm})$ を廊下の天井面に設置した。以下、排気量は排煙口からの 強制排出量を示し、排気未作動（排気量 $0 \mathrm{~m}^{3} / \mathrm{h}$ ）は、強制排出を行わ ず下流端側面の開口からの流出を示す。
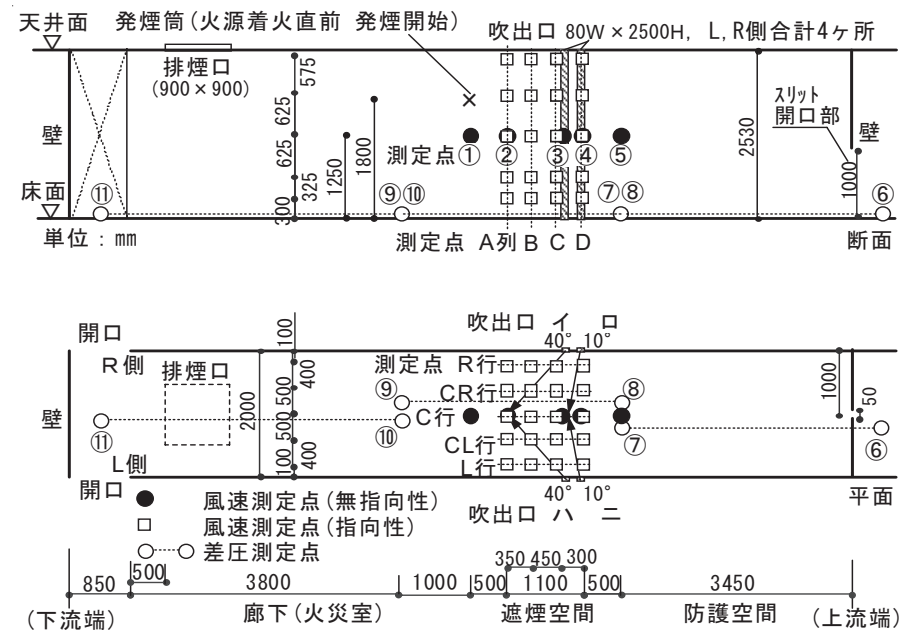

図 2 実験室および風速、圧力測定点
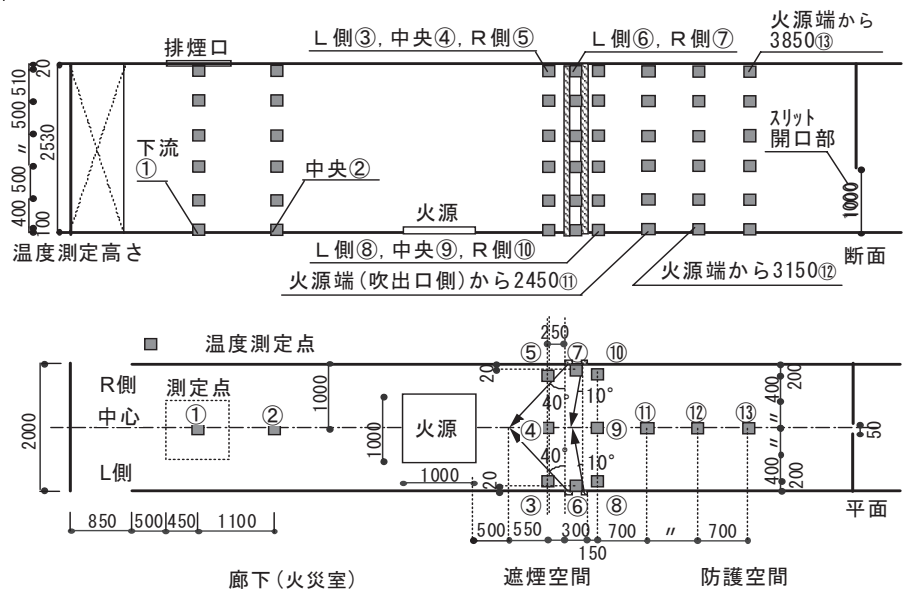

図 3 火源および温度測定点

表 1 気流・熱性状の実験ケー入

\begin{tabular}{|c|c|c|c|c|c|c|c|c|c|}
\hline \multirow{3}{*}{$\begin{array}{c}\text { 実験 } \\
\text { No. }\end{array}$} & \multirow{3}{*}{ 検討内容 } & \multirow{3}{*}{ 測定項目 } & \multicolumn{3}{|c|}{ 吹出角度 $\left({ }^{\circ}\right)$} & \multirow{3}{*}{$\begin{array}{c}\text { 給気量 } \\
Q a \\
\left(m^{3} / h\right)\end{array}$} & \multirow{3}{*}{$\begin{array}{c}\text { 排気量 } \\
Q s m \\
\left(\mathrm{~m}^{3} / \mathrm{h}\right)\end{array}$} & \multicolumn{2}{|c|}{ 開口面積 $\left(\mathrm{m}^{2}\right)$} \\
\hline & & & \multicolumn{2}{|c|}{ 水平方向 } & \multirow{2}{*}{$\begin{array}{l}\text { 垂直 } \\
\text { 方向 }\end{array}$} & & & \multirow{2}{*}{$\begin{array}{c}\text { 廊下 } \\
{\left[\begin{array}{l}\text { 下流端 } \\
\text { 側面 }\end{array}\right.}\end{array}$} & \multirow{2}{*}{$\begin{array}{c}\text { 防護 } \\
\text { 空間 } \\
\text { (上流端) }\end{array}$} \\
\hline & & & 下流 & 上流 & & & & & \\
\hline $\mathrm{A} 0^{\prime}$ & 蓄煙 & 温度 & & & & 0 & 0 & & \\
\hline $\mathrm{A} 1$ & 気流性状 & 風速 & & & & $150 \mathrm{c}$ & 0 & & \\
\hline A2 A2' & $(\mathrm{A} 1 \sim \mathrm{A} 4)$ & （X 方向） & & & & 15,000 & 15,000 & & \\
\hline A3 A3' & & & & & +40 & & 0 & 4.3 & 0.05 \\
\hline A4 A4' & $\begin{array}{c}\text { 熱性状 } \\
\left(\text { A2' } \sim A 4^{\prime}\right)\end{array}$ & 温度 & 40 & 10 & $\sim$ & 18,000 & 18,000 & $(100 \%)$ & $(1 \%)$ \\
\hline A5 & 各空間の & 差圧、風速 & & & & 15,000 & 0 & & \\
\hline A6 & 圧力差 & $\begin{array}{c}(X, Y, Z \text { 方向 } \\
\text { の合成値) }\end{array}$ & & & & 18,000 & 0 & (\%)は & 開口率 \\
\hline
\end{tabular}

表 2 測定機器

\begin{tabular}{|c|c|c|c|c|}
\hline 測定項目 & 機器名 & $\begin{array}{l}\text { 測定 } \\
\text { 方法 }\end{array}$ & $\begin{array}{c}\text { 間隔 } \\
(\text { 秒 })\end{array}$ & $\begin{array}{c}\text { 測定時間 } \\
\text { (秒) }\end{array}$ \\
\hline 温度 & $\mathrm{T}$ 型、 $\mathrm{K}$ 型熱電対 $(\phi=0.32 \mathrm{~mm})$ & 固定 & 1.0 & - \\
\hline $\begin{array}{c}\text { 風速 } \\
\text { (指向性) }\end{array}$ & $\begin{array}{l}\text { 三次元超音波風速計 } \\
\text { KAIJYO }\end{array}$ & 移動 & 0.1 & 60.0 \\
\hline 風速(無指向性) & KANOMAX MODEL 6542 & 固定 & 0.1 & 60.0 \\
\hline 圧力差 & 日本特殊測器 KPD2001 & 固定 & 0.1 & 60.0 \\
\hline 記録計 & 横河電機 DC100 & - & 1.0 & - \\
\hline $\begin{array}{c}\mathrm{CO}_{2} \text { 濃度計 } \\
\text { (非分散型赤外線式) }\end{array}$ & $\begin{array}{l}\left.\text { 富士電機 ZRG 型(測定点 } Y_{s m}, Y_{d}\right) \\
\text { 光明理化学工業 UM-280L(測定点 } Y_{c} \text { ) }\end{array}$ & 固定 & $\frac{1.0}{1.0}$ & - \\
\hline
\end{tabular}



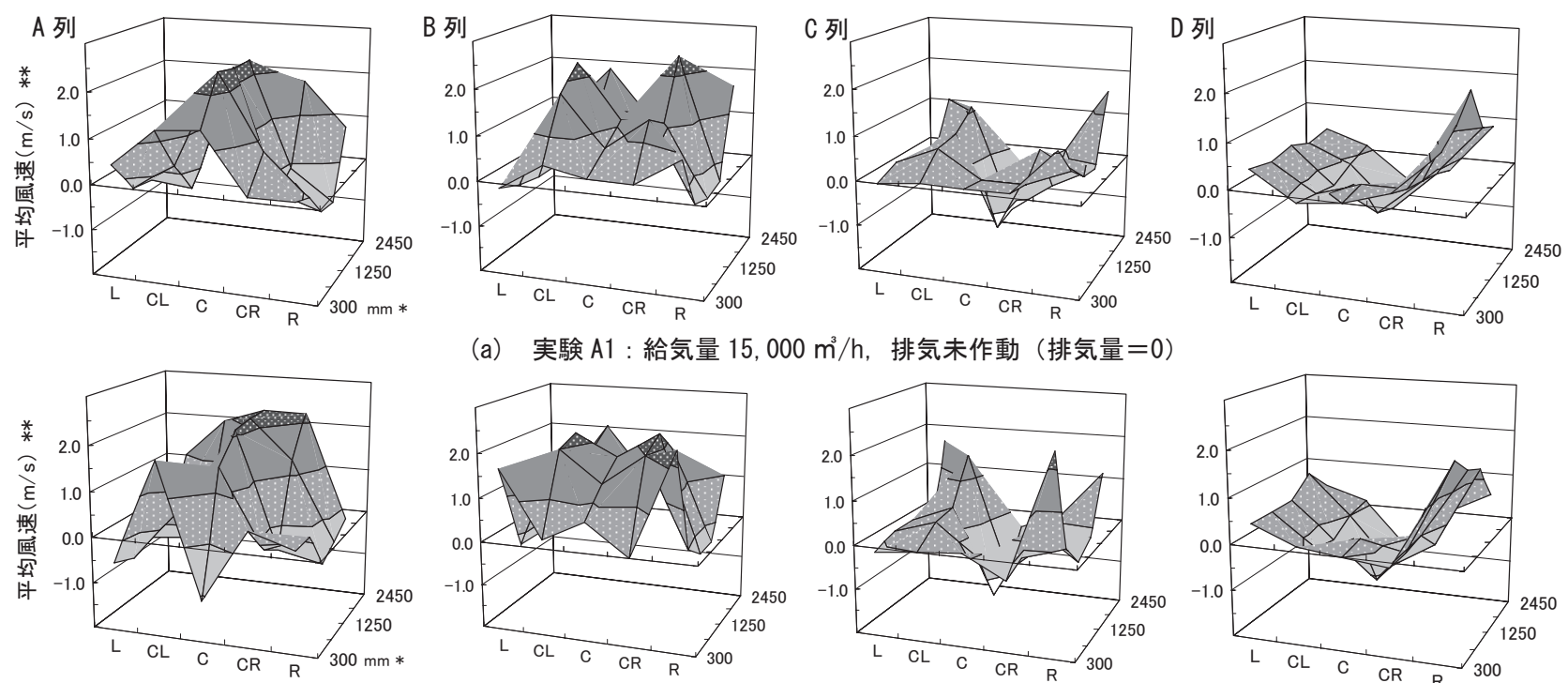

（a）実験 $\mathrm{A} 1$ : 給気量 $15,000 \mathrm{~m}^{3} / \mathrm{h}$ ，排気未作動（排気量 $=0$ )
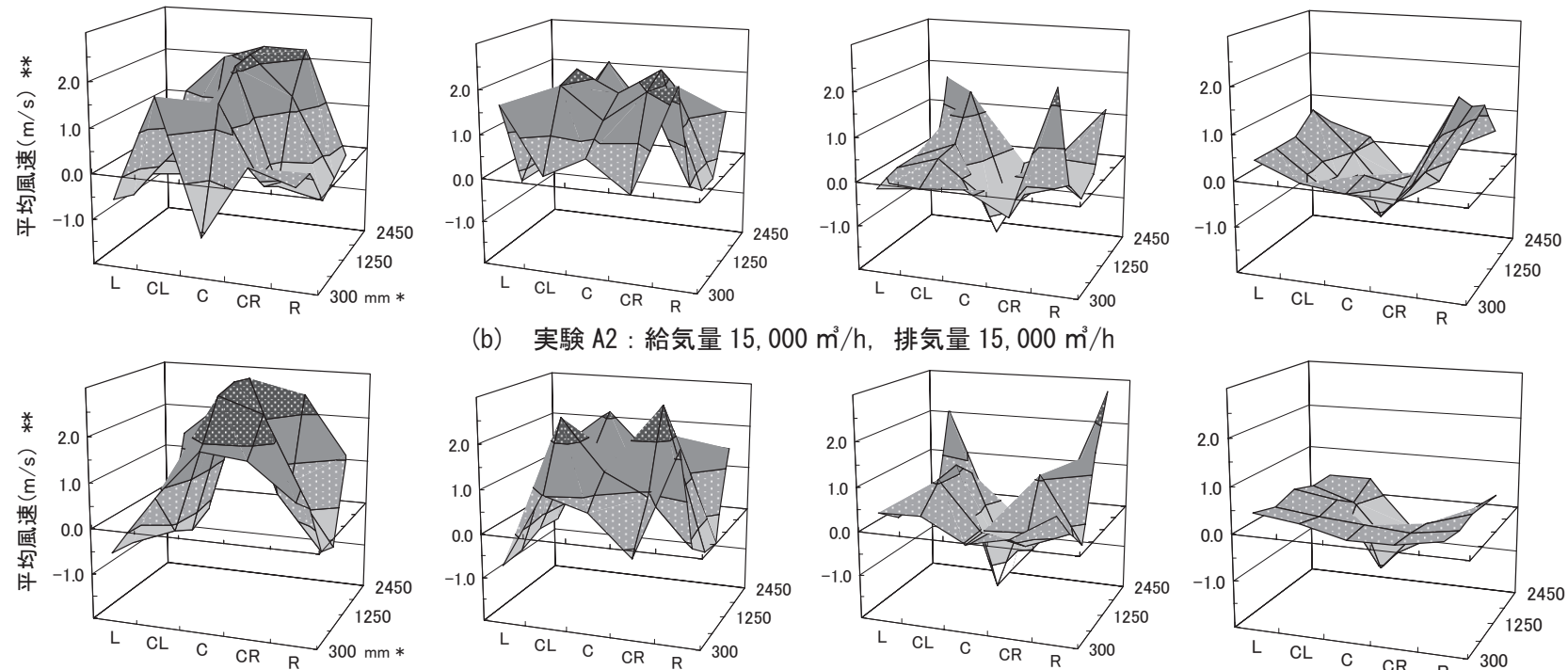

(b) 実験 A2：給気量 $15,000 \mathrm{~m}^{3} / \mathrm{h}$, 排気量 $15,000 \mathrm{~m}^{3} / \mathrm{h}$
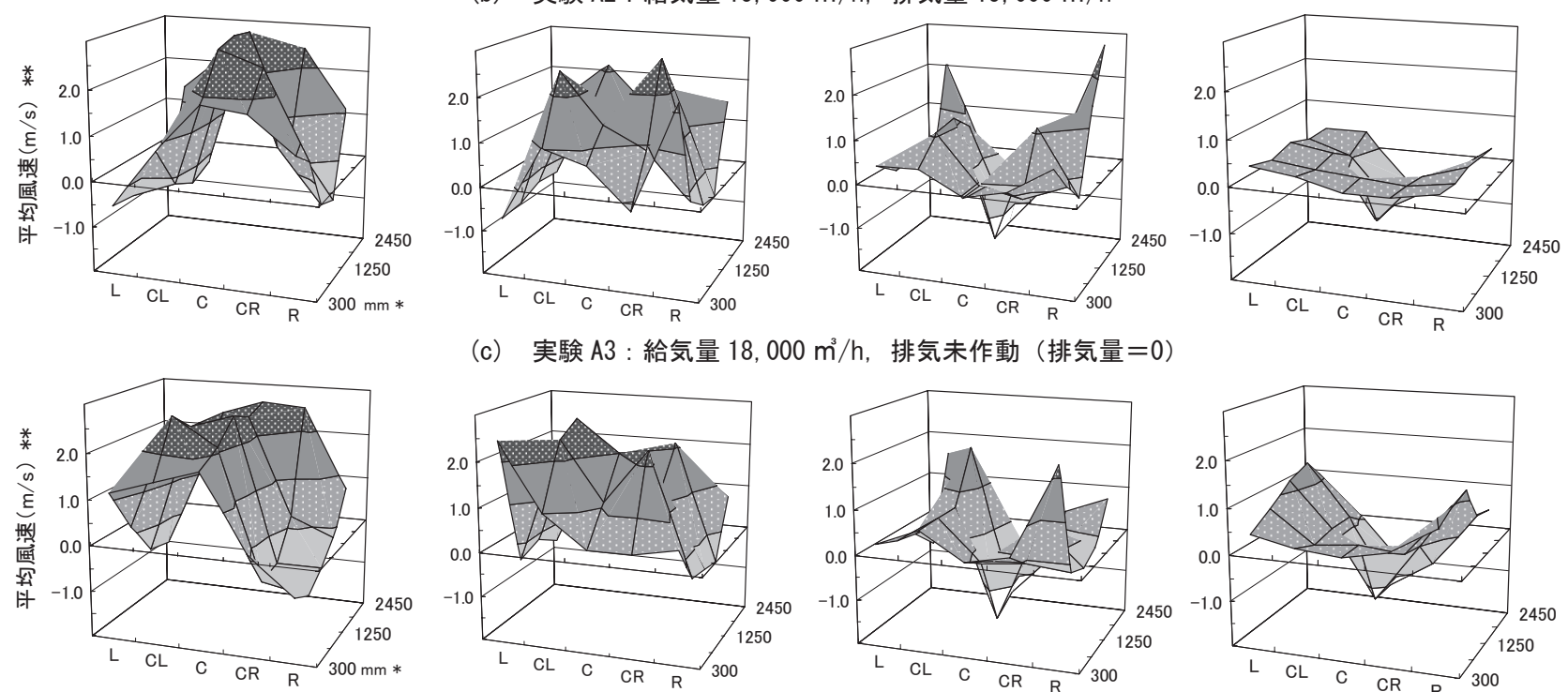

（c）実験 A3：給気量 $18,000 \mathrm{~m}^{3} / \mathrm{h}$, 排気未作動（排気量 $=0$ )
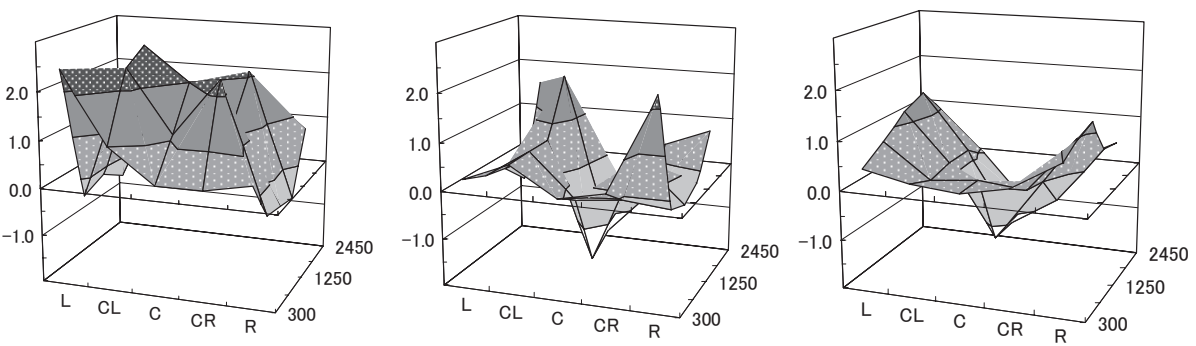

(d) 実験 A4: 給気量 $18,000 \mathrm{~m}^{3} / \mathrm{h}$, 排気量 $18,000 \mathrm{~m}^{3} / \mathrm{h}$ *床面からの高さ $300,625,1250,1875,2450(\mathrm{~mm})$ を示す。 $* *$ 防護空間から廊下方向を正値とする。

図 $4 \quad \mathrm{X}$ 方向気流性状の実測值（AＤ 列：図 2)

\section{2 実験内容}

実験ケ一久（A1〜 A6, A0', A2’～A4'）を表 1、測定機器を表 2 に示す。気 流性状の実験（A1〜A4, 図 2) では、指向性がある三次元超音波風速 計を用い、移動測定によって実測を行った。

各空間の圧力差の実験（A5, A6, 図 2）では、無指向性の風速計と各空 間に圧力計を設置し、測定を行った。圧力差を測定する際、動圧を測 定しない様に、測定点チュー゙の先端に風圧板を設置した。

熱性状の実験（A0', A2' 〜 A4'，図 3）では、実験の安全上、設置可能 な $1000 \mathrm{~mm} \times 1000 \mathrm{~mm}$ のアルコール゚ンに火源（図 3, 燃料：メ夕ルール12L, 発熱 速度 $400 \mathrm{~kW}$ ) を焚き、火災室および遮煙空間、防護空間の温度上昇 (温 度差 $\Delta T(\mathrm{~K}))$ を測定した。火源からの放射および壁や床面からの再 放射による温度上昇を防ぐため、アル簿の傘を防護空間前面(図 3, 測 定点 8)〜(10)、防護空間内 (11)〜 (13) の熱電対 ( $T$ 型, K 型) に設置した。 なお、気流性状に影響が及ぶことを防ぐため、火源に近い遮煙空間の 測定点(3)〜 (7)にはアル䇴の傘は設置しなかった。

\section{3 等温下での気流性状測定}

合成気流の測定結果を図 4 (a) 〜 (d) (A1〜A4) に示す。（測定点 $A \sim D$ 列および $L \sim R$ 行の位置を図 2 に示す。）風速は三次元超音波風速計の 60 秒平均測定值から、X 方向（防護空間から廊下方向）成分のみの流 れを抽出し、防護空間から廊下方向の流れを正値とした。A 列および B 列より、排気の作動、未作動に関係なく、正值方向の気流を確認し た。この気流により、防護空間への煙の侵入を防ぐ遮煙効果が得られ ている。

吹出口イ, 八 (図 2) より下流側に位置する廊下壁に近い測定点 L 行と $\mathrm{R}$ 行（A 列, B 列の (a)〜 (d) 全て) において、負值方向の気流がみられ るが、これは吹出気流の誘引による。発煙筒の煙による目視観察から、 この誘引気流は、水平方向 $40^{\circ}$ の吹出口の気流軸と A, B 列の廊下 (火 災室）壁の間で留まり、さらに、C，D列中央部一の逆方向の流れは見 られず、遮煙効果には影響を及ぼしていない。吹出口近傍では、吹出 気流による誘引を生じ、本シ久テムに特有な気流性状を呈している。 
廊下中央部（図 2，測定点 C 行）のC 列およびD 列において、負值方 向の気流を確認した。発煙筒の煙による目視観察結果によれば、吹出 ロイ, 八およびロ, 二からの合成気流は、遮煙空間の下流側 (A 列, B 列) の廊下中央部では、正值方向であり遮煙効果をもたらしているが、吹 出口ロ, 二からの合成気流は遮煙空間の上流側（C 列, D 列）の廊下中 央部においては、上述の負值方向の気流も発生させている。この負值 方向の気流は、防護空間に対して新鮮空気を供給する副次的な換気効 果をもたらすと考えられる。

\section{4 システ人作動時の風速と圧力差}

遮煙空間内と、遮煙空間に接する廊下開口部および防護空間の入口 部における 5 点の風速 (図 2, 測定点(1)～(5))の測定結果 (A5, A6) を図 5 に、各空間の圧力差を図 6 に示寸。各空間の圧力は、実験室外-防護 空間 (6)-77) では防護空間側を正值、防護空間-廊下 (8)-(9) では、防 護空間側を正值、廊下-実験室外 (10-(11) では、廊下側を正值として設 定した。

図 5 より、気流軸が交わる廊下開口部 (2) の風速が約 3. 3 4. $1 \mathrm{~m} / \mathrm{s}$ と最 も大きく、防護空間の入口部(5) は約 $0.3 \mathrm{~m} / \mathrm{s}$ と最も小さい。なお、図 5 の測定值は、X, Y, Z 方向の合成值であるため、図 4 の X 方向のみの測定 結果と差違がある。これより、遮煙空間から廊下側では煙の侵入を防 ぐ速い気流が、また、防護空間内では滞留者に影響を及ぼさない微風 速が確認された。

図 6 より、防護空間-廊下間（図 2, 測定点 (8)-(9)）の圧力差は、給気量 の変化にかかわらず、ごくわずかに防護空間が大きい。よって、給気 した空気が下流側から排出されるように設計することで、本㳄市ムの作 動が各空間に過大な圧力差を生じさせることはない。

\section{5 熱性状測定}

実験 $\mathrm{A} 0{ }^{\prime}$ (蓄煙)の各測定点の温度上昇（最大值）を図 7 (a) に示す。 火源前面（中央(4)）では、天井面近傍（床上 $2510 \mathrm{~mm}$ ）において約 200 $\mathrm{K}$ 上昇した。火災室（下流(1) では、周壁への失熱および下流端側面

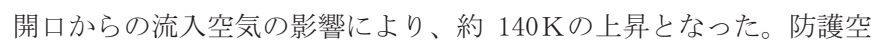
間内 (13) では、床上 1500〜2510mm まで約 100〜 125K上昇した。

実験 A2’（給排気量 $15,000 \mathrm{~m}^{3} / \mathrm{h} ）, A 4^{\prime}\left(18,000 \mathrm{~m}^{3} / \mathrm{h}\right)$ の各点の温度上 昇（火災室の温度上昇がほぼ定常となった 300 秒時点）を図 7 (b), (c) に示す。火災室では、特に下流（1) においてケ一毎にほぼ一定の温度 勾配が形成された。中央（2) では、天井面近傍で A2’ が約 $140 \mathrm{~K}$ 、 A4' が約 $100 \mathrm{~K}$ 上昇した。火源前面（3〜(5)）の床上 $2000 \mathrm{~mm}$ では、A2' の L 側で約 $80 \mathrm{~K} 、 A 4 '$ の 側で約 $50 \mathrm{~K}$ 上昇した。L 側の温度が高いの は、吹出口からの気流により、高温空気が吹出口側へ誘引されたため と考えられる。吹出口間（6)，(7) では、A2’で約 4〜15K、A4’で約 2〜8Kの上昇に留まった。さらに、防護空間前面（8〜佃）では、A2' で約 3〜8K、A4’で約 2〜 6Kの上昇に抑制されている。

防護空間内（11)～(13)）の温度上昇を図 8 に示す。実験 A2'（給排気量 $15,000 \mathrm{~m}^{3} / \mathrm{h}$ ) は約 $2 \sim 6 \mathrm{~K}$ 上昇し、若干の温度勾配を生じた。 $\mathrm{A} 4{ }^{\prime}$ $\left(18,000 \mathrm{~m}^{3} / \mathrm{h}\right)$ は約 $3 \mathrm{~K}$ 以下となり、高さ方向の温度差は小さい。 以上より、A2', $A 4$ ' の吹出口間と防護空間の温度上昇は小さく、ま た、両者の比較から、給排気量の増加に従い温度上昇も抑制されるこ とが確認された。特に $\mathrm{A} 4$ ' (給排気量 $18,000 \mathrm{~m}^{3} / \mathrm{h}$ ) は、上述の様に吹 出口間の温度上昇は約 2 $8 \mathrm{~K}$ 、防護空間前面は約 2 6K Kであり、火源 からの熱の影響は小さい。さらに、防護空間内は約 $2 \sim 3 \mathrm{~K}$ でほぼ一様 な温度上昇分布となっていることから、火源の熱放射の影響はあるが、

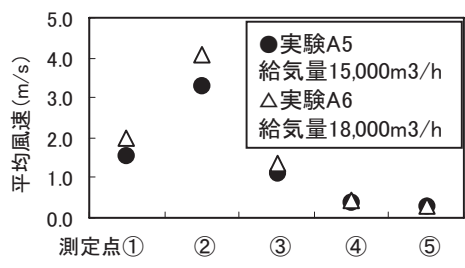

図 5 遮煙空間内外における風速

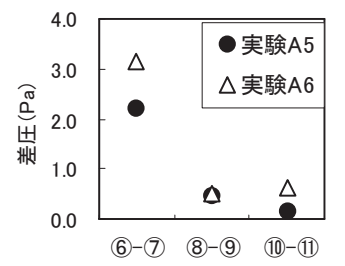

図 6 各空間の圧力差

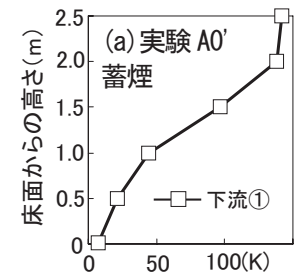

(1) 火災室 (測定点 : 図 3)

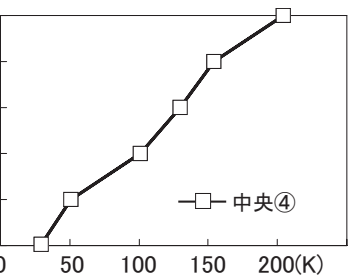

(口) 火源前面

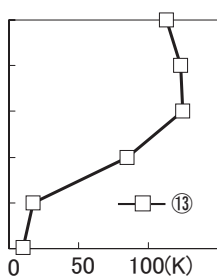

(ハ) 防護空間内
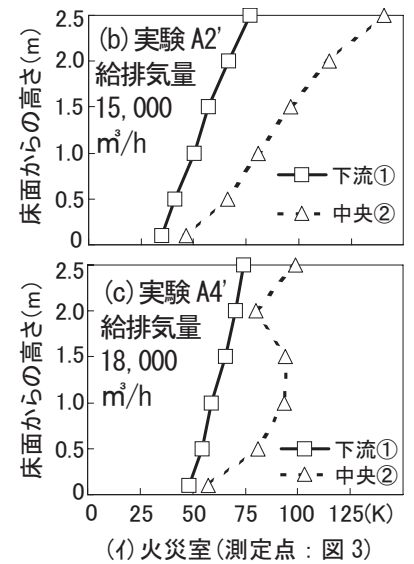
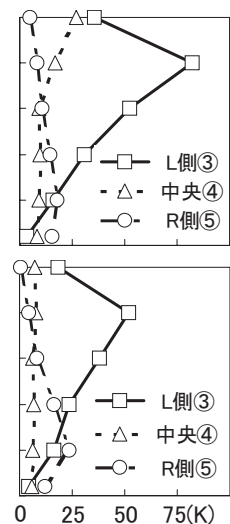

(口) 火源前面
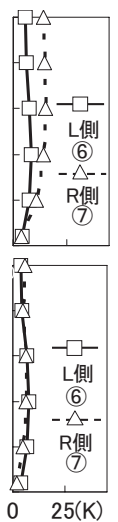

吹出口間

図 7 温度上昇の実測值（火源 $400 \mathrm{~kW}$ )
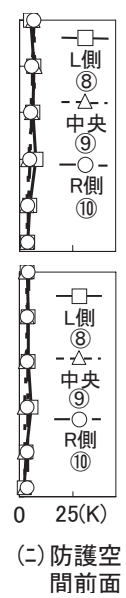

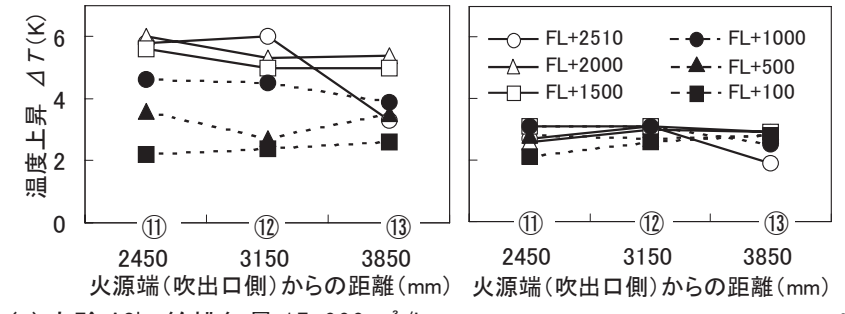

(a) 実験 A2' : 給排気量 $15,000 \mathrm{~m}^{3} / \mathrm{h} \quad$ (b) 実験 $A 4^{\prime}$ : 給排気量 $18,000 \mathrm{~m}^{3} / \mathrm{h}$

対流によるものは小さいと考えられる。従って、A4’の防護空間側の気 流性状において、発熱のない条件下との差は僅少と考えられる。

\section{5. 気流性状・熱性状の CFD 解析 \\ 5.1 解析条件}

実験 A3, A3' (給気量 $18,000 \mathrm{~m}^{3} / \mathrm{h}$, 排気未作動)について、CFD 解析を行 い予測精度を検証した。解析では実験室内を、約 26 万の構造格子 $\left(\right.$ メッシュ $^{8) 9)}$ で再現した。

4 ヶ所の吹出口は、各々高さ方向に 15 分割、合計 60 分割し、実験条 件と同じ吹出角度を再現した。吹出口の風量は合計 $18,000 \mathrm{~m}^{3} / \mathrm{h}$ で、 4 ヶ所の吹出口は同風量の $4500 \mathrm{~m}^{3} / \mathrm{h}$ とし、吹出風速の初速分布は測定値 を基に設定した。熱性状解析は簡易圧縮により密度変化を考慮した。 ${ }^{9}$ 
両側壁からの吹出し気流は、実験に際しては同風量を設定しても、わ ずかな差があるため、廊下中心線で対称には合成されず、片側に偏流し て安定した状態になることが観察された。吹出口から下流の境界条件は、 廊下等の閉鎖空間や開放空間の設定で異なり、CFD 解析等により流れ の詳細を予測する必要がある。解析至゙゙ル、計算条件を注 1)に示す。

\section{2 解析結果}

（1）気流性状

X 方向 (防護空間から廊下方向)の風速実測值（A3）と解析値の比較を 図 9 に示寸。比較対象の測定点は、吹出口近傍以外の $A \sim D$ 列の CL, C, CR 行 (図 2) とした。解析結果を以下にまとめる。

( i ) A 列 (図 9) および B 列において、防護空間から廊下方向への遮煙効 果をもたら寸気流 (平均風速が正值) が確認された。なお、A 列 CL 行と $\mathrm{CR}$ 行および $\mathrm{B}$ 列 $\mathrm{CR}$ 行は、解析值と測定值との間に一部差違が認めら れるが、これは実験時の給気量の左右バランスや施工精度によるものと 考えられる。

$\mathrm{A}$ 列 CL 行の実測值は、気流の誘引作用が大きいため中間高さで風速が

(a) $A$ 列
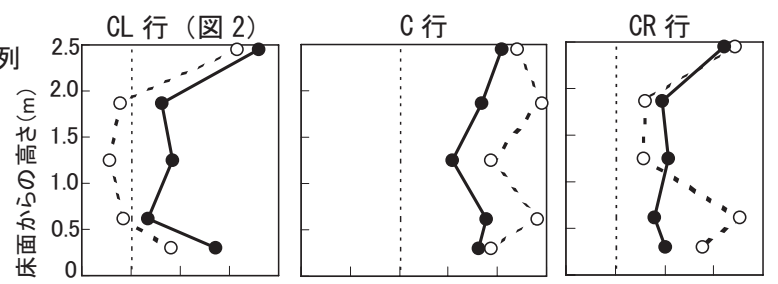

(b) B 列
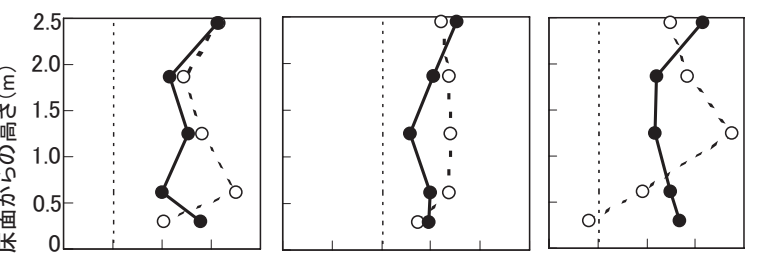

(c) C 列
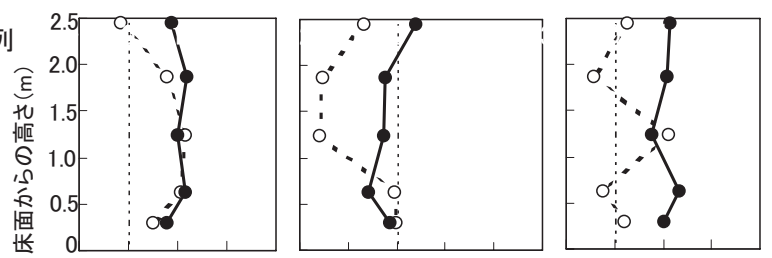

(d) D 列
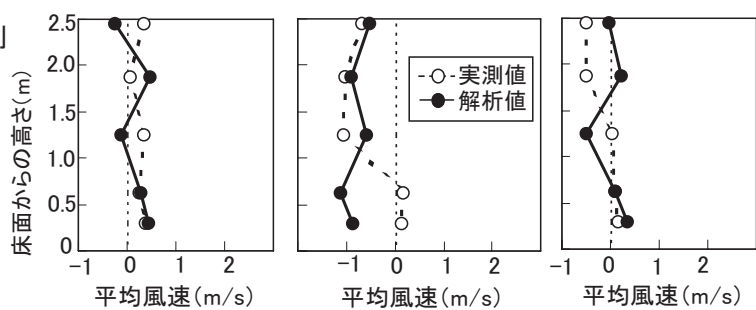

図 $9 x$ 方向(防護空間から廊下方向)の風速実測值 (実験 A3 : 給気量 $18,000 \mathrm{~m}^{3} / \mathrm{h}$ ) と解析值
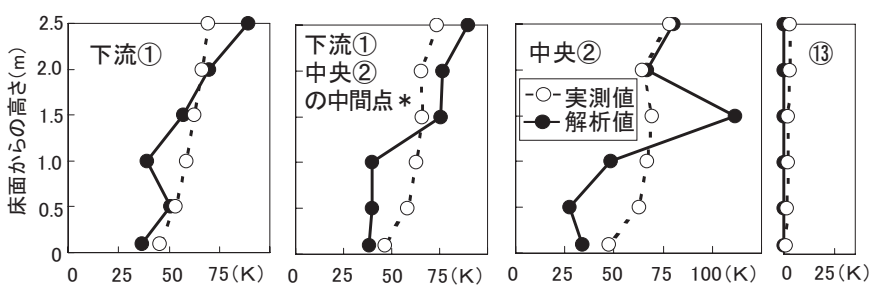

(1) 火災室 (測定点: 図 3)

$*$ 実測值は下流(1)と中央(2)の平均值 $\quad$ (口) 防護空間内

図 10 温度上昇実測值 (実験 A3' : 火源 $400 \mathrm{~kW}$, 給気量 $18,000 \mathrm{~m}^{3} / \mathrm{h}$ ) と解析值
減少したと考えられ、負值となっている。

(ii )C 列およびD 列それぞれの廊下中央部 (C 行) において、副次的な換 気効果をもたらす気流 (平均風速が負值) が確認された。なお、C 列 $\mathrm{CR}$ 行において、解析值と測定值の間に差違が認められるが、この測定点 は吹出口ロ, ニからの気流が衝突する複雑な気流性状の領域であり、 さらに、B 列の CR 行の影響を受けたためと考えられる。

(iii)B, C, D 列の CL 行、A, B, D 列の C 行、D 列の CR 行では、概初解析值 は測定值に近い分布形が示された。

（2）熱性状

火災室および防護空間内の温度上昇実測值 (A3’) と解析值の比較を図 10 に示す。比較対象の測定点は、火㷋室の下流(1)、下流(1)と中央(2)の 中間点、中央(2)およ゙防護空間内の(13)とした。火源の発熱速度は、 $400 \mathrm{~kW}$ を入力した。

(13)では解析值の温度は、ほとんど上昇せず、実測值と同様に遮煙が再 現された。(2)では、解析值の熱気流は火源から発生したプルームの影響 を受け、床上 $1500 \mathrm{~mm}$ 近辺での温度上昇が大きい。これに対して実測 值は、ほぼ上下一定勾配の温度分布となっている。(1)と(2)の中間点で は、熱気流は(2)より下流に位置するため拡散し、解析值の温度分布は なだらかとなっている。(1)では、解析值はほぼ上下一定勾配の温度分 布となり実測值に近い。

\section{6. 遮煙効果・換気効果の実験 \\ 6.1 実験内容}

本実験では、（i ）火災室での㶴ル燃焼で $\mathrm{CO}_{2}$ を発生させ、防護空間 の $\mathrm{CO}_{2}$ 濃度の上昇から遮煙効果を確認、（ii）防護空間に供給した $\mathrm{CO}_{2}$ 濃度の減衰から防護空間の換気効果の確認、を目的とした。防火防煙 シかッ夕一の遮煙性能試験 ${ }^{10)}$ では、片側を加圧した状態の漏気量を求める ことが規定されているが、本シ行ムでは片側を加圧した状態での試験は 不可なので、上述の方法を採用した。

\section{2 実験方法}

実験室の開口条件は、廊下側については下流端側面の開口を開放 (開口率 100\%) した。防護空間側の上流端は、階段室扉等の漏気（開 口率 1\%）を想定して、吸引フアンによる一定量の排気 $(Q d)$ を行った。 なお、吸引フアンの吸引量は、上流端の壁に列归状開口（図 2)を設置した 上で、下流端側面の開口を開放（開口率 100\%）し、給気量および排気 量は実験時と同様 $\left(12,000 \mathrm{~m}^{3} / \mathrm{h}, 15,000 \mathrm{~m}^{3} / \mathrm{h}, 18,000 \mathrm{~m}^{3} / \mathrm{h}\right.$ の 3 種類）と して、給気フアン、排気フアンの運転を行い、防護空間からこの则外状開口 を通じて外部へ流出する漏気量と同量とした。実験は、給気つアり、排 気フア、吸引フアりを運転し、吹出口から給気して排煙口から排気した状 態で行った。

(1) 遮煙効果実験（図 11）

前出の火源を焚き（図 3 , 発熱速度 $400 \mathrm{~kW}$ )、火災室の代表的な $\mathrm{CO}_{2}$ 濃度 を示すと想定される排煙口内 $\left(Y_{s m}\right)$ 、防護空間中央 $\left(Y_{c}\right)$ 、吸引空気 $(Y d)$ の 3 点の $\mathrm{CO}_{2}$ 濃度の変化を測定した。火苂室から防護空間へ の漏気に伴う $\mathrm{CO}_{2}$ 濃度の变化を測定して、遮煙効果を判定した。

(2) 換気効果実験(図 12)

$\mathrm{CO}_{2}$ が室内に十分にかくはんするよう、防護空間で扇風機を運転しな がら、防護空間の天井面から $\mathrm{CO}_{2}$ を 1 分間当り約 $28.5 \mathrm{~L}$ 供給した。防 護空間の $\mathrm{CO}_{2}$ 濃度が定常状態になった後、 $\mathrm{CO}_{2}$ の供給を停止し、 $\mathrm{CO}_{2}$ 濃 度の減衰を測定して、換気効果を判定した。なお、扇風機は防護空間 


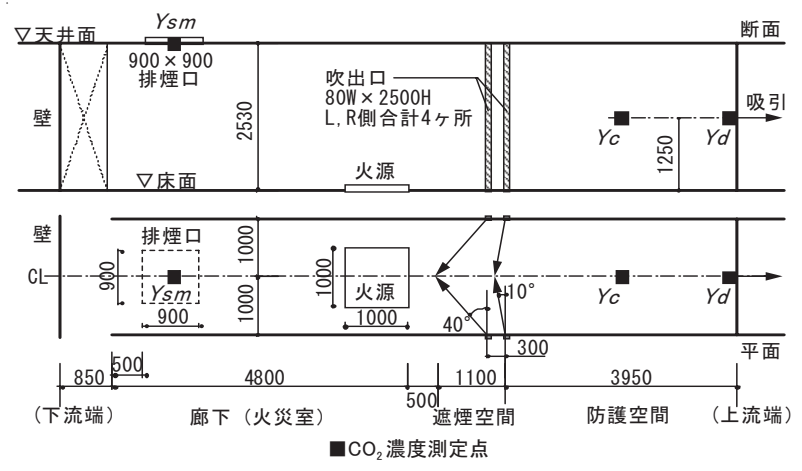

図 11 遮煙効果実験
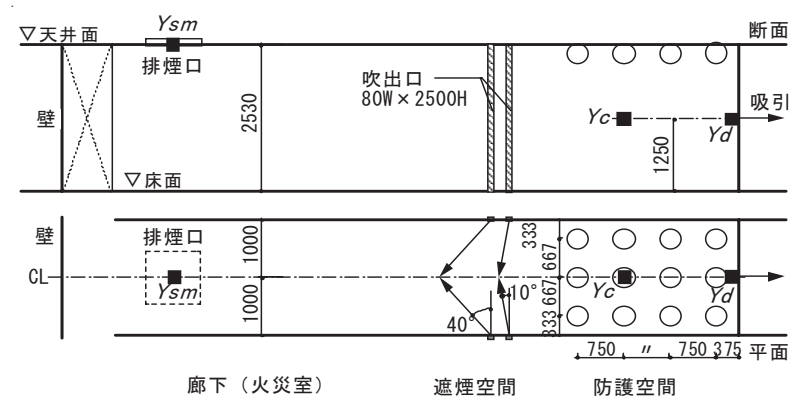

口 $\mathrm{CO}_{2}$ 濃度測定点、 $\mathrm{OCO}_{2}$ 放出位置(天井・合計 12 箇所)

図 12 換気効果実験

の上流端に設置しており、給排気を行った状態での測定点(4)（図 2) の風速値（無指向性）は、扇風機の未作動時に対して、作動時は $0.1 \mathrm{~m} / \mathrm{s}$ 程度の増加であり、気流や遮煙性状一の影響はほとんどない と考えられる。

\section{(3) 給気未作動時との比較}

給気および排気の効果を判定するために、給気未作動かつ排気作動時、 給気および排気とも未作動時の遮煙効果および換気効果を、(1) (2) と同様の方法で判定した。

\section{3 実験 $\top-$ ス}

遮煙効果・換気効果の実験个一入 $(B 1 \sim B 6)$ を表 3 に示す。遮煙効果 換気効果を給排気量で比較するため、4 章の実験 (表 1) と同様の $15,000 \mathrm{~m}^{3} / \mathrm{h} 、 18,000 \mathrm{~m}^{3} / \mathrm{h}$ に加え、 $12,000 \mathrm{~m}^{3} / \mathrm{h}$ の 3 通りの給排気量で実験 を行った。給気未作動時との比較の実験ケース(B7〜B12)を表 4 に示寸。

\section{7. 遮煙効果・換気効果の実験結果と考察}

\section{1 実験結果}

(1) 遮煙効果実験（給排気作動時）

図 $13(\mathrm{a})$ に $\mathrm{CO}_{2}$ 濃度上昇值の変化を、表 5 に各測定点でのピーク 3 分間 の平均の $\mathrm{CO}_{2}$ 濃度上昇値を示す。いずれの場合も、火災室（排煙口内） の $\mathrm{CO}_{2}$ 濃度 $\left(Y_{s m}\right)$ の上昇にくらべ、防護空間中央 $\left(Y_{c}\right)$ 、防護空間の 吸引空気 $(Y d)$ の上昇は小さい。

給排気量 $12,000 \mathrm{~m}^{3} / \mathrm{h}(\mathrm{B} 1), 15,000 \mathrm{~m}^{3} / \mathrm{h}(\mathrm{B} 2), 18,000 \mathrm{~m}^{3} / \mathrm{h}(\mathrm{B} 3)$ の $\mathrm{CO}_{2}$ 濃度 上昇比は、給排気量 $18,000 \mathrm{~m}^{3} / \mathrm{h}$ の場合を 1.0 としたとき、防護空間中 央では 9.9, 1.7 1.0 であり、吸引空気では 4.1，1.3，1.0 となって いる。 $12,000 \mathrm{~m}^{3} / \mathrm{h}$ の場合は、 $\mathrm{CO}_{2}$ 濃度上昇比が大きい。

(2) 換気効果実験（給排気作動時）

図 $13(\mathrm{~b})$ に $\mathrm{CO}_{2}$ 濃度が定常となった後、 $\mathrm{CO}_{2}$ の供給を停止した状態での 防護空間の $\mathrm{CO}_{2}$ 濃度上昇值の変化を示す。給排気量 $15,000 \mathrm{~m}^{3} / \mathrm{h}(\mathrm{B} 5)$,
表 3 遮煙効果・換気効果 (給排気作動時) の実験个一久

\begin{tabular}{|c|c|c|c|c|c|}
\hline $\begin{array}{l}\text { 実験 } \\
\text { No. }\end{array}$ & $\begin{array}{l}\text { 検討 } \\
\text { 内容 } \\
\end{array}$ & $\begin{array}{l}\text { 測定 } \\
\text { 項目 } \\
\end{array}$ & $\begin{array}{c}\text { 給気量 } Q a \\
\left(\mathrm{~m}^{3} / \mathrm{h}\right)\end{array}$ & $\begin{array}{c}\text { 排気量 } Q s m \\
\left(\mathrm{~m}^{3} / \mathrm{h}\right)\end{array}$ & $\begin{array}{c}\text { 吸引量 } Q d \\
\left(\mathrm{~m}^{3} / \mathrm{h}\right) \\
\end{array}$ \\
\hline $\mathrm{B} 1$ & \multirow{3}{*}{$\begin{array}{l}\text { 遮煙 } \\
\text { 効果 }\end{array}$} & \multirow{3}{*}{$\begin{array}{l}\mathrm{CO}_{2} \\
\text { 濃度 }\end{array}$} & 12,000 & 12,000 & 108 \\
\hline B2 & & & 15,000 & 15,000 & 132 \\
\hline B3 & & & 18,000 & 18,000 & 162 \\
\hline B4 & \multirow{3}{*}{$\begin{array}{l}\text { 換気 } \\
\text { 効果 }\end{array}$} & \multirow{3}{*}{$\begin{array}{l}\mathrm{CO}_{2} \\
\text { 濃度 }\end{array}$} & 12,000 & 12,000 & 108 \\
\hline B5 & & & 15,000 & 15,000 & 132 \\
\hline B6 & & & 18,000 & 18,000 & 162 \\
\hline
\end{tabular}

表 4 遮煙効果・換気効果 (給気未作動時)の実験歼久

\begin{tabular}{|c|c|c|c|c|c|}
\hline $\begin{array}{c}\text { 実験 } \\
\text { No. }\end{array}$ & $\begin{array}{l}\text { 検討 } \\
\text { 内容 }\end{array}$ & $\begin{array}{l}\text { 測定 } \\
\text { 項目 }\end{array}$ & $\begin{array}{c}\text { 給気量 } Q a \\
\left(\mathrm{~m}^{3} / \mathrm{h}\right)\end{array}$ & $\begin{array}{c}\text { 排気量 } Q s m \\
\left(\mathrm{~m}^{3} / \mathrm{h}\right)\end{array}$ & $\begin{array}{c}\text { 吸引量 } Q d \\
\left(\mathrm{~m}^{3} / \mathrm{h}\right)\end{array}$ \\
\hline B7 & \multirow{3}{*}{$\begin{array}{l}\text { 遮煙 } \\
\text { 効果 }\end{array}$} & \multirow{3}{*}{$\begin{array}{c}\mathrm{CO}_{2} \\
\text { 濃度 }\end{array}$} & \multirow{3}{*}{0} & 0 & \multirow{3}{*}{0} \\
\hline B8 & & & & 15,000 & \\
\hline B9 & & & & 18,000 & \\
\hline B10 & \multirow{3}{*}{$\begin{array}{l}\text { 換気 } \\
\text { 効果 }\end{array}$} & \multirow{3}{*}{$\begin{array}{c}\mathrm{CO}_{2} \\
\text { 濃度 }\end{array}$} & \multirow{3}{*}{0} & 0 & \multirow{3}{*}{0} \\
\hline B11 & & & & 15,000 & \\
\hline B12 & & & & 18,000 & \\
\hline
\end{tabular}
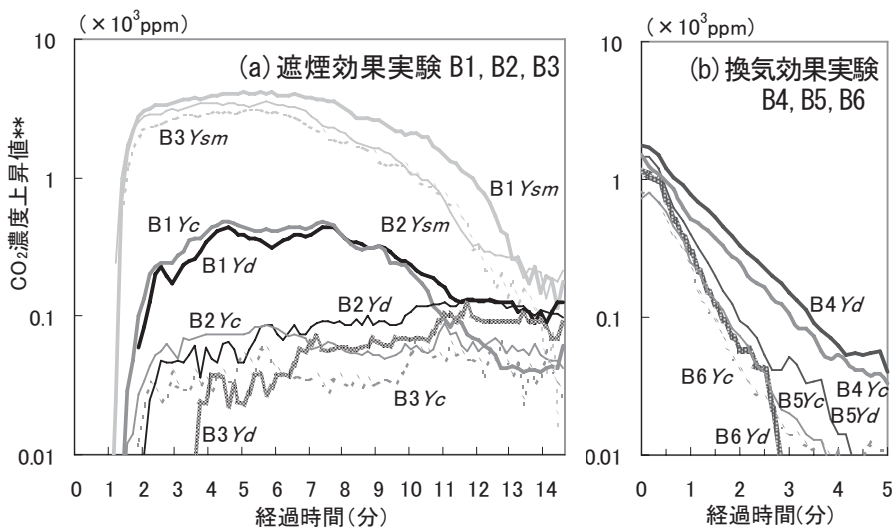

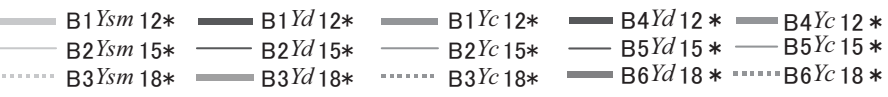

* 12,15, 18 は給排気量各 $12,000,15,000,18,000 \mathrm{~m}^{3} / \mathrm{h}$

$* * \mathrm{~B} 1 \sim \mathrm{B} 6$ の排煙口内 $Y_{s m}$, 防護空間吸引空気 $Y d$, 防護空間中央 $Y_{c}$ の $\mathrm{CO}_{2}$ 濃度 上昇值は外気 $Y_{a}(380 \mathrm{ppm})$ との差

図 $13 \mathrm{CO}_{2}$ 濃度上昇值の変化(給排気作動時)
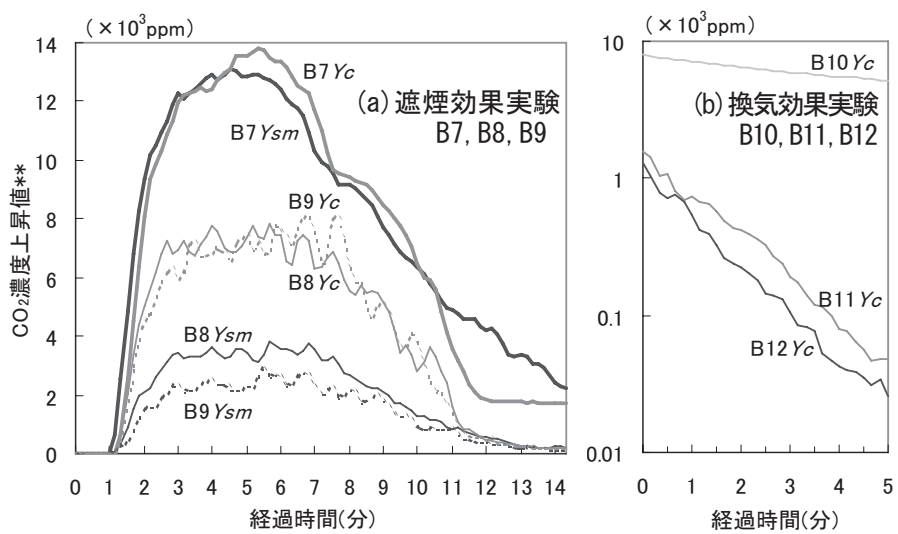

-

B7 $Y_{s m}$ 排気未作動 B $B Y_{c}$ 排気未作動 B8 $Y_{s m}$ 排気作動 $15 *-B 8 Y_{c}$ 排気作動 $15 *$ B9 $Y_{s m}$ 排気作動 $18 * \ldots . . . . . . B 9 Y_{c}$ 排気作動 $18 *$

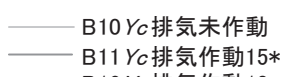

B11 $Y_{C}$ 排気作動15*

* 排気作動 15,18 は排気量各 $15,000,18,000 \mathrm{~m}^{3} / \mathrm{h}$

$* *$ (1)B7 B B12 の排煙口内 $Y_{s m}$, 防護空間中央 $Y_{c}$ の $C_{2}$ 濃度上昇値は外気 $Y_{a}$ (380ppm) との差 (2) $Y_{C}$ は ZRG 型により測定 (3)上流端は閉鎖 (開口率:0\%)

図 $14 \mathrm{CO}_{2}$ 濃度上昇值の変化 (給気未作動時) 
表 5 各測定点のピーク 3 分間平均の $\mathrm{CO}_{2}$ 濃度上昇値

\begin{tabular}{cccc}
\hline $\begin{array}{c}\text { 給排気量 } \\
Q a, Q s m\left(\mathrm{~m}^{3} / \mathrm{h}\right)\end{array}$ & $\begin{array}{c}\text { 排煙口内 } \\
Y_{s m}-380 *(\mathrm{ppm})\end{array}$ & $\begin{array}{c}\text { 防護空間中央 } \\
\boldsymbol{Y}_{\boldsymbol{c}}-380 *(\mathrm{ppm})\end{array}$ & $\begin{array}{c}\text { 吸引空気 } \\
Y_{\boldsymbol{d}}-380 *(\mathrm{ppm})\end{array}$ \\
\hline $12,000(\mathrm{~B} 1)$ & 3994 & $437(9.9) * *$ & $376(4.1) * *$ \\
$15,000(\mathrm{~B} 2)$ & 3365 & $76(1.7) * *$ & $119(1.3) * *$ \\
$18,000(\mathrm{~B} 3)$ & 2950 & $44(1.0) * *$ & $92(1.0) * *$ \\
\hline
\end{tabular}

*380ppm : 外気 $\mathrm{CO}_{2}$ 濃度 $\quad * * 18,000 \mathrm{~m} / \mathrm{h}$ の場合を 1 とした $\mathrm{CO}_{2}$ 濃度上昇比

$18,000 \mathrm{~m}^{3} / \mathrm{h}$ （B6）のいずれの場合も、2 分以内で $100 \mathrm{ppm}$ 以下に減衰し た。JIS A1406（屋内換気量測定方法）の $\mathrm{CO}_{2}$ 濃度減少から換気量を求 める (1) 式を用いて、吸引空気の $\mathrm{CO}_{2}$ 濃度 $(Y d)$ の減衰から防護空間の 換気量 $Q$ を求めた。(7.2 参照)

$$
Q\left(\mathrm{~m}^{3} / \mathrm{h}\right)=2.303 \frac{V}{t} \log _{10} \frac{C_{1}-C_{0}}{C_{t}-C_{0}}
$$

（3） 給気未作動時との比較

遮煙効果については、図 14 (a) に示寸ように、防護空間中央の $\mathrm{CO}_{2}$ 濃度 上昇值は、排気量 $15,000 \mathrm{~m}^{3} / \mathrm{h}$ （B8）または $18,000 \mathrm{~m}^{3} / \mathrm{h}$ （B9）で約 7000 〜8000ppm であった。排気未作動のケース(B7) は 13,000ppm 以上となり、 本シ久テム作動時にくらべ大幅に高い。

換気効果は、図 14(b)（B11, B12）に示すように、排気を作動しても $\mathrm{CO}_{2}$ 濃度の減衰時間は長く、換気効果は低減する。防護空間中央の $\mathrm{CO}_{2}$ 濃度の減少から求めた防護空間の換気量は、排気未作動の B10 は約 $80 \mathrm{~m}^{3} / \mathrm{h}$ 。排気作動 $15,000 \mathrm{~m}^{3} / \mathrm{h}$ の B11 は約 $800 \mathrm{~m}^{3} / \mathrm{h}$ 、排気作動 $18,000 \mathrm{~m}^{3} / \mathrm{h}$ の B12 は約 $1000 \mathrm{~m}^{3} / \mathrm{h}$ である。本シ人テム作動時と給気未作動時の比較によ り、遮煙効果・換気効果が明確となった。

\section{2 遮煙効果・換気効果の算定}

(1) 計算玩゙

図 15 に火災室、防護空間廻りの空気の流出入を基にした遮煙・換気 の計算モデルおよび計算式 (2)〜 (5) を示す。火災室から防護空間へは

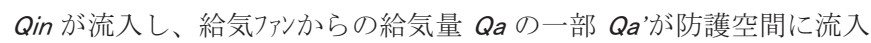
して、Qoutが火災室へ流出する。Qinの $\mathrm{CO}_{2}$ 濃度 Yin は排煙口内の Ysm とする。

(2) 算定結果 (表 6)

給気量 $Q a$ と $\operatorname{in}$ の比を侵入率 $S(Q \operatorname{in} / Q a)$ とする。開口率を下流端側 面を $100 \%$ 、上流端を $1 \%$ 相当とした場合に、S で $0.46 \% 、 18,000 \mathrm{~m}^{3} / \mathrm{h}$ で $0.38 \%$ である。（表 6, №.(1)）

開口率を下流端 $1 \%$ 、上流端 $1 \%$ 相当とした場合は、それぞれ $0.41 \%$, $0.13 \%$ (2)。下流端 1\%、上流端 40\% (扉 1 枚の面積相当) とした場 合は、 $0.75 \%, 0.41 \%$ (3)。(1)(2)で $Y d$ の代わりに防護空間中央の $Y_{C}$ を用いると、Sは(1) $0.29 \%, 0.18 \%$ 、(2)' $0.47 \%, 0.18 \%$ である。

Qa'による防護空間の換気回数 $\left(Q a^{\prime} / 20 \mathrm{~m}^{3}\right)$ は、給排気量 $15,000 \mathrm{~m}^{3} / \mathrm{h}$ で約 76 96 回/h、18,000m $\mathrm{m}^{3} / \mathrm{h}$ で約 98〜 115 回/h である。

防護空間の火災室に対する $\mathrm{CO}_{2}$ 濃度上昇值の比率 $R 1$ は、給排気量 $15,000 \mathrm{~m}^{3} / \mathrm{h}$ で $3.5 \%$ (1), $2.3 \%$ (1)' ) $18,000 \mathrm{~m}^{3} / \mathrm{h}$ で $3.1 \%$ (1), $1.5 \%$ (1)')。火災室の $\mathrm{CO}_{2}$ 濃度上昇值を蓄煙時（給排気未作動、13, 137ppm）とし た比率 R2 は、それぞれ $0.9 \%$ (1)，0.6\% (1)'および $0.7 \%$ (1)，0.3\% (1) ) であり、本㳄去による遮煙効果・換気効果が示されている。

火源が今回の実験より大きい場合でも、風量を増せば遮煙効果・換 気効果が得られると考えられるが、必要な風量との関係は今後の課題 である。

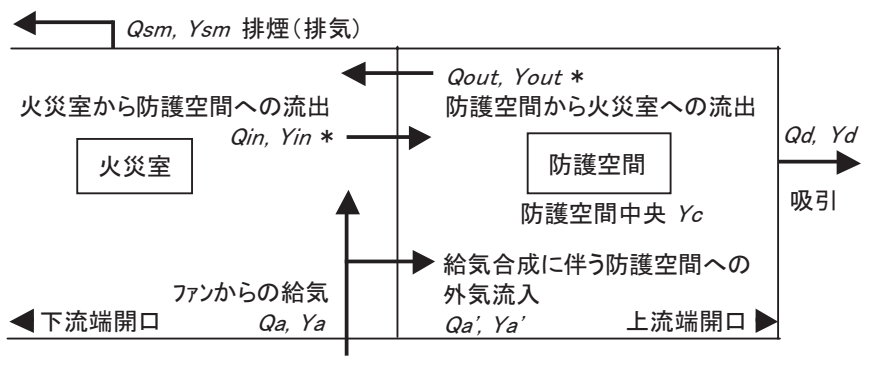

Qoa' $=Q a^{\prime}+$ Qin $=$ Quit $+Q d$

$\left(Y_{a^{\prime}} \times Q_{a^{\prime}}\right)+\left(Y_{\text {in }} \times Q_{\text {in }}\right)=\left(Y_{\text {out }} \times Q_{\text {out }}\right)+\left(Y_{d} \times Q d\right)$

$Q^{\prime}=\left(Y_{\text {out }} \times\left(Q_{o a^{\prime}}-Q d\right)+\left(Y_{d} \times Q d\right)-\left(Y_{\text {in }} \times Q_{o a^{\prime}}\right)\right) /\left(Y_{a^{\prime}}-Y_{\text {in }}\right) \cdots \cdots(4)$

$* Y_{\text {in }}=Y_{s m}$ 、 $Y_{\text {out }}=Y_{c}$ or $Y_{d}$ として $\mathrm{CO}_{2}$ 流出入量は(5)式による。

$\left(380 \times Q a^{\prime}\right)+\left(Y_{s m} \times Q_{i n}\right)=\left(Y_{c}\right.$ or $\left.Y_{d}\right) \times\left(Q^{\prime}+Q_{i n}\right)($ 表6) $\cdots \cdots \cdots(5)$

図 15 遮煙・換気の計算モデル

表 6 遮煙効果・換気効果（防護空間の $\mathrm{CO}_{2}$ 濃度、換気回数等）

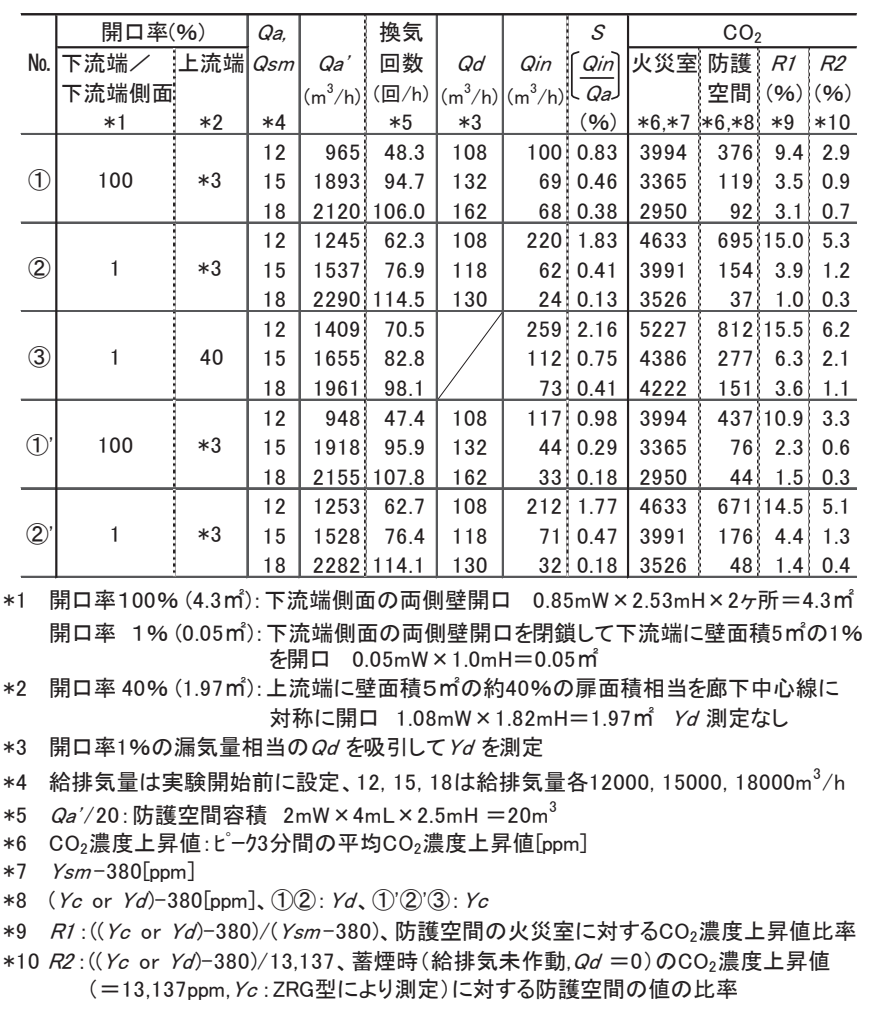

\section{3 防護空間の $\mathrm{CO}_{2}$ 濃度上昇予測}

防護空間の $\mathrm{CO}_{2}$ 濃度上昇について、昭和 48 年 建設省告示 第 2564 号の遮煙性能を有する防火防煙シャッ夕ーの区画と本シ久元をを予測して比較 した。算定は (6) 式による。

$$
C t\left(\mathrm{~m}^{3} / \mathrm{m}^{3}\right)-C_{o}=\left(k /\left(\operatorname{Qin}+Q a^{\prime}\right)\right) \times\left(1-\exp \left(-\left(\operatorname{Qin}+Q a^{\prime}\right) \frac{t}{V}\right)\right)
$$

本実験の防護空間 (容積: $20 \mathrm{~m}^{3}$ ) は、防火防煙シャッターの区画では、時間経 過に従い $\mathrm{CO}_{2}$ 濃度が上昇し、69 分後には約 $10,000 \mathrm{ppm}$ を超える。

本システムで給排気を作動した場合は、約 4 分後には定常值に達し

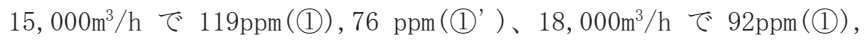
$44 \mathrm{ppm}$ (1)') となり、遮煙効果・換気効果の有効性が示されている。(図 16）なお、告示第 2564 号で定められている遮煙性能試験方法によれば、 試験体の両面における圧力差 $19.6 \mathrm{~Pa}$ において $0.2 \mathrm{~m}^{3} / \mathrm{m}^{2}$ ・ min 以下とす 


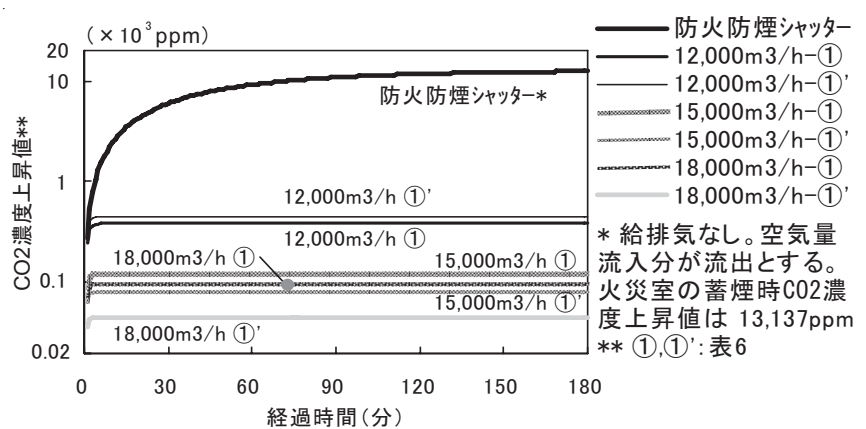

図 16 防護空間における $\mathrm{CO}_{2}$ 濃度上昇値の予測
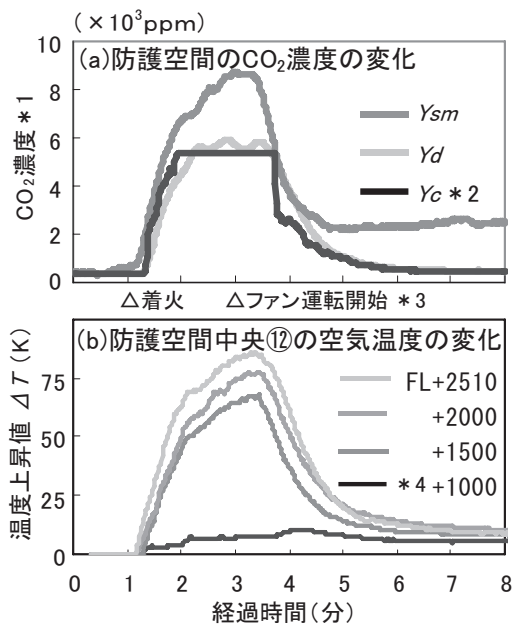

給排気量 $\cdot 18,000 \mathrm{~m}^{3} / \mathrm{h}$

上流端吸引量 $Q d: 162 \mathrm{~m} / \mathrm{h}$

下流端側面開口率 : $100 \%$ (表 6 )

火源 : $256 \mathrm{~kW}$

$\left[\begin{array}{l}\text { メタタール: } 12 \mathrm{~L} \\ \text { パソ: } 800 \mathrm{~mm} \times 800 \mathrm{~mm}\end{array}\right]$

$* 1 \mathrm{CO}_{2}$ 基準初期濃度 $380 \mathrm{ppm}$

$* 2 Y_{c}$ は測定可能最大值の 約 5000ppm を超えると 一定值となる。

*3 着火 2 分後に本シ行么を 運転

*4 床上 1500 2510 mm と $1000 \mathrm{~mm}$ では温度変化に 差違があり二層化した 分布となっている。

図 17 シ人テムを着火 2 分後に未作動状態から作動させた過渡応答

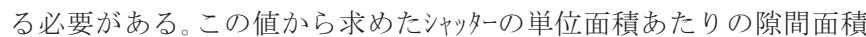
は、 $0.0008 \mathrm{~m}^{2} / \mathrm{m}^{2}$ となる。これより、火災室の平均温度を本実験時の $100^{\circ} \mathrm{C}$ とすると、平均圧力差は $2.7 \mathrm{~Pa}$ となり、シかッ多の単位面積漏気量 は、 $0.084 \mathrm{~m}^{3} / \mathrm{m}^{2} \cdot \min$ となる。

\section{4 システ出の過渡応答}

本シ久うムを未作動状態から作動させた過渡応答を図 17 に示す。着火 2 分後に給排気フアリを $18,000 \mathrm{~m}^{3} / \mathrm{h}$ で運転した。なお、この実験では、着火 からフア盗転開始までに 2 分間かかることから、他の遮煙効果実験と同 量のメタール (12L) で燃焼時のピーク継続時間を長くするため、 $800 \mathrm{~mm} \times$ $800 \mathrm{~mm}$ のアルコール゚ンを使用した。このときの発熱速度は $256 \mathrm{~kW}$ である。防 護空間中央の $\mathrm{CO}_{2}$ 濃度 $\left(Y_{C}\right)$ (最高約 $9000 \mathrm{ppm}$ )、温度上昇 (最大 $\Delta T$, 約 85 K）共にフアノ運転開始後、約 2 分で安全上支障ない值に低下している。

\section{8，避難者の遮煙効果への影響}

\section{1 実験内容}

実際の建物火災時には、遮煙空間を避難者が通過し、気流の抵抗体 として遮煙効果に影響を及ぼす。そこで、気流に影響を与えると予想 される位置に抵抗体として擬似人体を配置し、遮煙効果一の影響を確 認した。避難時の遮煙空間の通過時間は数秒であるが、安全側を考慮 し、実験中は常に擬似人体が存在とした。

\section{2 実験方法}

図 18 に示すように、遮煙空間付近に模擬避難者である擬似人体 $(237 \mathrm{~mm}$ W $\times 237 \mathrm{D} \times 1750 \mathrm{H})$ を配置して、火災室で姼ノルを燃焼させ、吸引 空気の $\mathrm{CO}_{2}$ 濃度 $(Y d)$ を測定した。擬似人体は図 19 の様に、12 通り
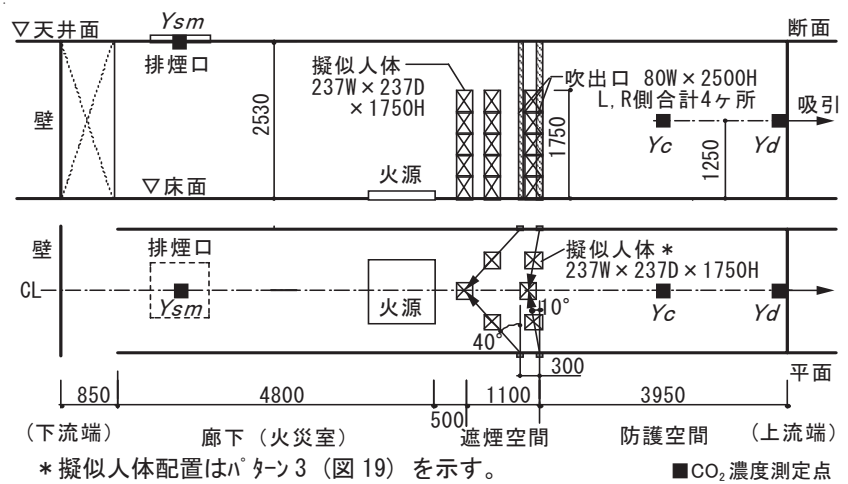

図 18 避難者影響実験
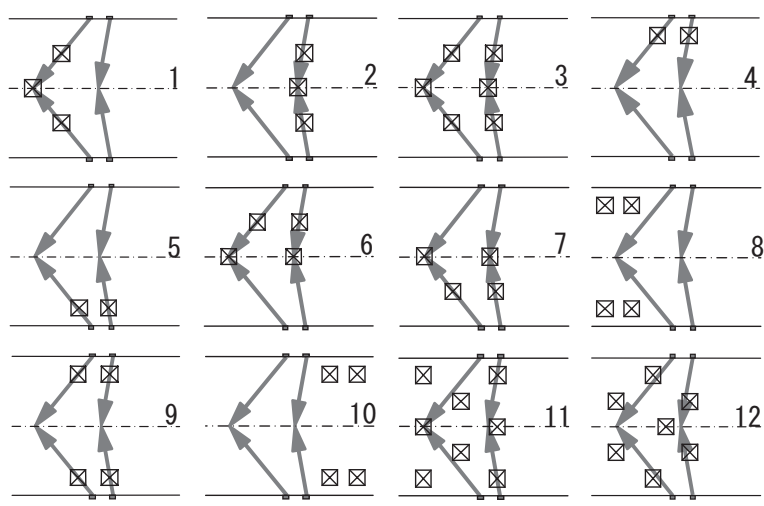

図 19 擬似人体 ( 抵抗体) の配置パタ-ン 1 12

の配置パターンとし、(1)廊下中心線に対称かつ気流軸上（パターン 1～3）、 (2) L または R 側どちらかに寄せて気流軸上（4～7)、(3) L または R 側の 壁際で 2 人ずつ $(8 \sim 10)$ 、(4)遮煙空間に多人数（11，12）とした。実 験は、 $15,000 \mathrm{~m}^{3} / \mathrm{h}$ と $18,000 \mathrm{~m}^{3} / \mathrm{h} の 2$ 種類の給排気量で行った。実験欠 一久（B13，B14）を表 7 に示す。

\section{3 実験結果}

表 8 に全ての擬似人体の配置パターンにおけるピーク 3 分間平均の吸引 空気の $\mathrm{CO}_{2}$ 濃度上昇值 $(Y d-380)$ を示す。また、図 20 に $\mathrm{CO}_{2}$ 濃度上昇 值が表 5 の吸引空気（Yd-380）の值（実験 B2：給排気量 $15,000 \mathrm{~m}^{3} / \mathrm{h}$ の場合 $119 p p m 、$ 実験 B3 : 給排気量 $18,000 \mathrm{~m}^{3} / \mathrm{h}$ の場合 $92 \mathrm{ppm}$ ) より大 きいパターン $(1,2,4,5,9)$ における防護空間の吸引空気の $\mathrm{CO}_{2}$ 濃度上昇 值（Yd-380）の変化を示す。

給排気量 $15,000 \mathrm{~m}^{3} / \mathrm{h}$ （表 8) では、擬似人体を配置していない場合の 上昇值 $(119 \mathrm{ppm})$ より大きい值を示したパターン 1, 4, 5, 9 の内、L, Rの片 側または両側の吹出口の直前に擬似人体を配置した 4, 5, 9 は、それぞ れ 351, 361, 214ppm であり、約 100〜140ppm の差となった。4, 5 の上昇 值の方が 9 より $140 \mathrm{ppm}$ 程度大きいが、擬似人体を $\mathrm{L}$ または $\mathrm{R} の$ 片側 の吹出口直前に配置したので、風速分布が片寄ったためと考えられる。 $40^{\circ}$ の気流軸上に配置のパターン 1 の差は $20 \mathrm{ppm}$ で小さい。その他のパタ ーンでは、Lまたは R 側の吹出口から $500 \mathrm{~mm}$ 離れた位置に配置した 3, 6, 7 や高密度に配置した 11,12 は、上昇值が小さい。給排気量 $18,000 \mathrm{~m}^{3} / \mathrm{h}$ (表 8)では、4，5 で上昇值はやや大きいが $15,000 \mathrm{~m}^{3} / \mathrm{h}$ にくらべて小さ い。1 $10^{\circ}$ の気流軸上に配置の 2 は $3 \mathrm{ppm}$ の差である。

実際の避難時における人体の移動を考慮すると、遮煙効果への影響 は小さいと考えられる。 
表 7 遮煙効果（抵抗体有）の実験坵

\begin{tabular}{cccccc}
\hline $\begin{array}{c}\text { 実験 } \\
\text { No. }\end{array}$ & $\begin{array}{c}\text { 検討 } \\
\text { 内容 }\end{array}$ & $\begin{array}{c}\text { 測定 } \\
\text { 項目 }\end{array}$ & $\begin{array}{c}\text { 給気量 } Q \boldsymbol{a} \\
\left(\mathrm{m}^{3} / \mathrm{h}\right)\end{array}$ & $\begin{array}{c}\text { 排気量 } Q s m \\
\left(\mathrm{~m}^{3} / \mathrm{h}\right)\end{array}$ & $\begin{array}{c}\text { 吸引量 } Q d * \\
\left(\mathrm{~m}^{3} / \mathrm{h}\right)\end{array}$ \\
\hline $\mathrm{B} 13$ & 遮煙 & $\mathrm{CO}_{2}$ & 15,000 & 15,000 & 132 \\
\cline { 5 - 6 } B14 & 効果 & 濃度 & 18,000 & 18,000 & 162 \\
\hline
\end{tabular}

* Qdは上流端より吸引、下流端側面の開口は開放（開口率 100\%)

表 8 ピーク 3 分間平均の吸引空気の $\mathrm{CO}_{2}$ 濃度上昇值 $(Y d-380 *)$

\begin{tabular}{|c|c|c|c|c|c|c|c|c|c|c|c|c|c|}
\hline \multirow{2}{*}{$\begin{array}{c}\text { 給排気量 } \\
\text { Qa, Qsm } \\
\left(\mathrm{m}^{3} / \mathrm{h}\right)\end{array}$} & \multirow{2}{*}{$\begin{array}{c}\mathrm{CO}_{2} \text { 濃度 } \\
\text { 上昇値 } \\
(\mathrm{ppm})\end{array}$} & \multicolumn{12}{|c|}{ 配置パターン } \\
\hline & & 1 & 2 & 3 & 4 & 5 & 6 & 7 & 8 & 9 & 10 & 11 & 12 \\
\hline 15,000 (B13) & \multirow{2}{*}{$Y d-380 *$} & 139 & 105 & 32 & 351 & 361 & 26 & 70 & 111 & 214 & 91 & 85 & 115 \\
\hline 18,000 (B14) & & 63 & 95 & 87 & 123 & 112 & 55 & 73 & 90 & 71 & 80 & 70 & 68 \\
\hline
\end{tabular}
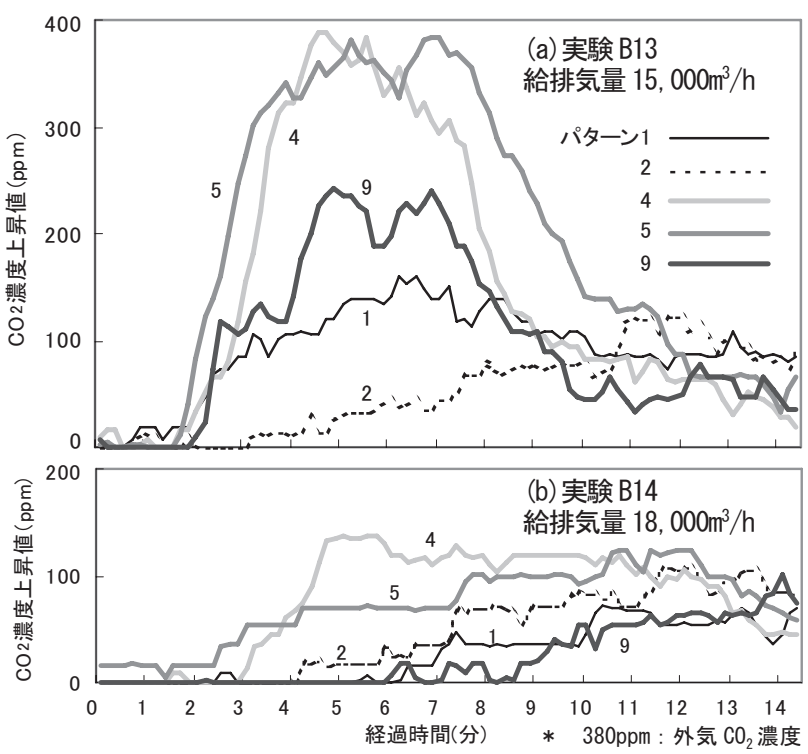

図 $20 \mathrm{CO}_{2}$ 濃度上昇值 $(Y d-380 *)$ の変化

9. まとめ

(1) 基礎実験として、発熱がない条件下における気流性状測定により、 遮煙効果と副次的な換気効果をもたらす気流を確認した。

(2) $400 \mathrm{~kW}$ 火源の熱性状測定では、廊下 (火災室) の天井面の温度上 昇に対し、防護空間の温度上昇は抑えられ、発熱の影響が小さい ことを確認した。

(3) $\mathrm{CO}_{2}$ 濃度測定結果から侵入率、換気回数等の性能值を算定した。

(4) 避難者の遮煙効果への影響が小さいことを明らかにした。また、 防護空間入口部の風速は静穏状態であり、気流による避難者への 影響は小さいことを確認した。

\section{謝辞}

本実験は、独立行政法人建築研究所の施設を賃借して行った。実験 にあたっては、同研究所の萩原一郎氏，林 吉彦氏，仁井大策氏の協 力を、 $\mathrm{CO}_{2}$ 濃度の測定にあたっては、同研究所の吉田正志氏の協力を 得た。また、本研究の実施に際しては、大成建設技術也夕一の小林 裕 氏、樋渡 潔氏の協力を得た。ここに謝意を表します。
〈記 号〉

$Q$ : 換気量 $\left(\mathrm{m}^{3} / \mathrm{h}\right) \quad Q d$ : 吸引量 $\left(\mathrm{m}^{3} / \mathrm{h}\right) \quad T$ : 温度 $(\mathrm{K})$

Qin : 防護空間への火災室からの流入量 $\left(\mathrm{m}^{3} / \mathrm{h}\right)$

Qout : 防護空間から火災室への流出量 $\left(\mathrm{m}^{3} / \mathrm{h}\right)$

$Q a$ : (外気) 給気量 $\left(\mathrm{m}^{3} / \mathrm{h}\right) \quad Q a^{\prime}$ : 防護空間への外気流入量 $\left(\mathrm{m}^{3} / \mathrm{h}\right)$

Qoa' : 防護空間 $一$ 流入量合計 (相当換気量) $\left(\mathrm{m}^{3} / \mathrm{h}\right)$

$Q s m$ : 排気量 $\left(\mathrm{m}^{3} / \mathrm{h}\right) \quad Y d$ : 防護空間の吸引空気 $\mathrm{CO}_{2}$ 濃度 $(\mathrm{ppm})$

$Y_{\text {in }}$ : 火災室 $\mathrm{CO}_{2}$ 濃度 $(\mathrm{ppm}) \quad Y_{\boldsymbol{C}}$ : 防護空間中央 $\mathrm{CO}_{2}$ 濃度 $(\mathrm{ppm})$

Yout : 防護空間 $\mathrm{CO}_{2}$ 濃度 $(\mathrm{ppm}) \quad Y s m$ : 排煙口内 $\mathrm{CO}_{2}$ 濃度 $(\mathrm{ppm})$

$Y a$ : 外気 $\mathrm{CO}_{2}$ 濃度 $(380 \mathrm{ppm}) \quad Y^{\prime}{ }^{\prime}$ : 流入外気 $\mathrm{CO}_{2}$ 濃度 $(380 \mathrm{ppm})$

$S \quad$ : 侵入率 $(\mathrm{Qin} / \mathrm{Qa}) \quad R i \quad \mathrm{CO}_{2}$ 濃度上昇比率 $(\%)(i=1,2)$

$C_{1}:$ 第 1 回目の測定時刻 $(t=0)$ における室内 $\mathrm{CO}_{2}$ 濃度 $\left(\mathrm{m}^{3} / \mathrm{m}^{3}\right)$

$C_{t}: t$ 時間後における室内 $\mathrm{CO}_{2}$ 濃度 $\left(\mathrm{m}^{3} / \mathrm{m}^{3}\right) \quad k: \mathrm{CO}_{2}$ 増加量 $\left(\mathrm{m}^{3} / \mathrm{h}\right)$

Co : 給気 $\mathrm{CO}_{2}$ 濃度 $\left(\mathrm{m}^{3} / \mathrm{m}^{3}\right) \quad V$ : 室気積 $\left(\mathrm{m}^{3}\right)$

$t$ : 第 1 回目の測定時刻からの経過時間 $(\mathrm{h})$

注

注 1) 気流・熱性状の CFD 解析

補表 1 水平噴流計算条件 ${ }^{8)}$ 9)

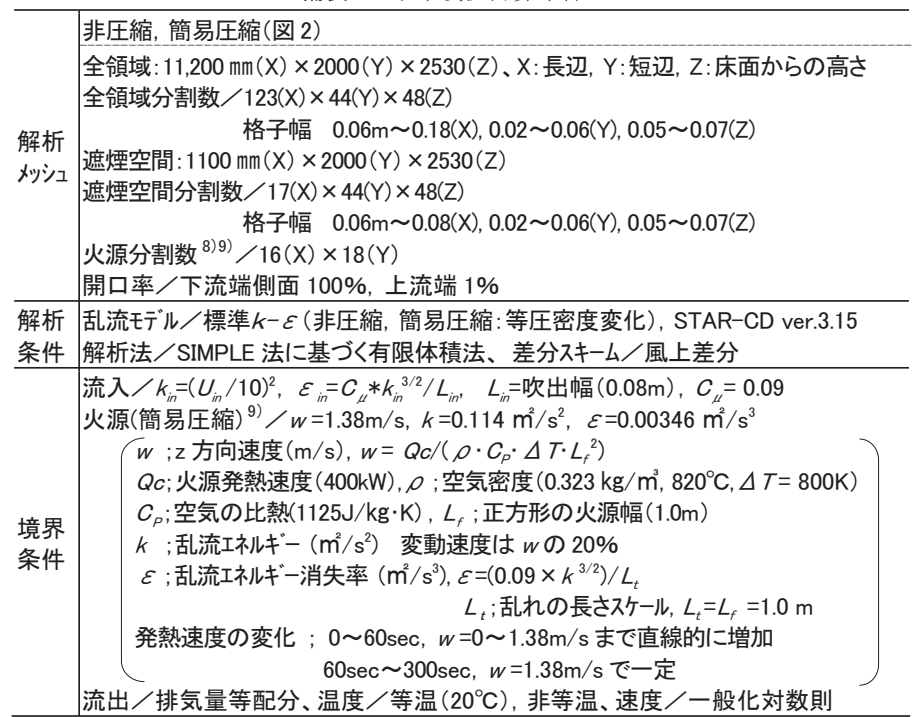

参考文献

1) 原 哲夫, 高橋一郎, 寺尾良雄, 塙 正司, 笠原 勲：附室加圧煙制御シ久テム の作動特性実測, 日本建築学会大会学術講演梗概集, (防火) pp. 47〜 48, 1997.9

2) 原 哲夫 : 高層集合住宅の付室加圧排煙シ行么に関する研究, 日本建築学会大 会学術講演梗概集，（防火） pp. 123〜124，2002.8

3) 中浜慎司, 笠原 勲, 森川泰成: 階段加圧防煙㳄么 40 研究 汉公のの概要と性 能検証実験, 日本建築学会大会学術講演梗概集, (防火) pp. 79〜82, 2003.9

4) 原 哲夫 : ゾーンモデルによる煙流動特性予測の基礎的考察に基づくCFD 解析の 性能設定，日本火災学会論文集，Vol.49, No.2, pp.43～55, 1999. 12

5) 中野美奈, 油野健志, 林 吉彦, 永野紳一郎, 山名俊男, 若松孝旺 : 給気位 置が遮煙開口部の流量分布形成に与える影響に関する実験的考察(その 5 追 加実験), 日本建築学会大会学術講演梗概集, (防火) pp.203 204, 2004. 8

6) 中浜慎司, 原 哲夫, 嵐城太郎, 山名俊男, 樋渡 潔 : 水平噴流式煙制御 汣㕕に関する実験的研究（その 3 ）気流性状の測定，日本建築学会大会学術 講演梗概集，（防火）pp.259〜262, 2007.8

7) 嵐城太郎，原 哲夫，中浜慎司，山名俊男，小林 裕 : 水平噴流式煙制御次 テムに関する実験的研究（その 4) 遮煙効果の検討, 日本建築学会大会学術講 演梗概集，(防火） pp. 263〜266, 2007.8

8) Hara,T. and Kato, S. :Numerical simulation of thermal plumes in free space using the standard $k$ - $\varepsilon$ model, Fire Safety Journal, Vol.39, pp.105-129, 2004

9) Hara,T. and Kato, S. :Numerical Simulation of Fire Plume-Induced Ceiling Jets Using the Standard $k-\varepsilon$ Model, Fire Technology, Vol.42, pp.131-160, 2006

10) 山名俊男，須藤昌照 : 遮煙性試験装置を用いた区画部材の性能評価，日本建 築学会大会学術講演梗概集，（防火） pp. 153～154，1998.9 